\title{
Effects of Smoking on the Level of Lipase Enzyme and Lipid Profile in Blood Serum of Young Smokers
}

\author{
Qussay Noori Raddam', Moafaq Mutlak Zeidan² \\ ${ }^{I}$ Assistant Professor, Biology Department, Education College, Iraqi University, Iraq, \\ ${ }^{2}$ Assistant Professor, Biology Department, Sciences College, Tikrit University, Tikrit, Iraq
}

\begin{abstract}
Cigarette smoking is a major risk factor for heart disease and peripheral vascular disorders. The cardiovascular diseases among smokers can be predicted by the levels of lipid profile. The objective of the present study is to analyse the effects of smoking on the lipid profile and lipase levels among Iraqi smokers as well as to identify the morbidity risk among smokers and non-smokers. A cross-sectional study $(n=50)$ was designed including smokers $(\mathrm{n}=40)$ and nonsmokers $(\mathrm{n}=10)$ as a control group. The lipid profile and lipase level tests were performed after overnight fasting.The lipid profile and lipase levels were found to be significantly $(\mathrm{p} \leq 0.05)$ increased in the smoker group as compared to non-smoker group. Total cholesterol and triglyceride (TG) levels were found to be increased $194.24 \pm 37.04 \mathrm{mg} / \mathrm{dl}$ and $173.87 \pm 44.96 \mathrm{mg} / \mathrm{dl}$ in the smoker group as compared to control $(165.35 \pm 23.6 \mathrm{mg} / \mathrm{dl}$ and $106.7 \pm 43.4 \mathrm{mg} / \mathrm{dl})$, respectively. Serum high-density lipoprotein cholesterol (HDL) concentration was decreased to $46.30 \pm 7.1 \mathrm{mg} / \mathrm{dl}$ as compared to control group $64.15 \pm 8.8 \mathrm{mg} / \mathrm{dl}$.The smoker group showed significant increased in the serum LDL $(103.16 \pm 21.43 \mathrm{mg} / \mathrm{dl})$ and VLDL $(44.78 \pm 8.9 \mathrm{mg} / \mathrm{dl})$ levels as compared to control group $(77.06 \pm 20.5 \mathrm{md} / \mathrm{dl}$ and $24.14 \pm 8.8 \mathrm{mg} / \mathrm{dl}$, respectively). Similarly, the smoker group showed decreased in serum lipase level (28.35 \pm 78.3 ) as compared to the control group (37.65 \pm 9.7$)$. Smoking is associated with many risk factors of heart and vascular diseases which can evaluated by the elevated levels of total cholesterol, TG, LDL and VLDL. However, preventive strategies are needed to avoid the future cardiovascular diseases and in supporting the benefits of quitting smoking.
\end{abstract}

Keywords: Smoking, Lipid profile, Lipase, Blood serum, Vascular diseases.

\section{Introduction}

Tobacco smoking is the most prevalent addictive disorderand the leading preventable cause of morbidity andmortality worldwide, which in turn causes devastating health problems including heart disease, lung disease and cancer. Smoking harms almost every organ of the body. The world has an estimated more than one billion smokers, approx. One fifth of the world's population ${ }^{1}$. In developed countries tobacco wasre sponsible for $24 \%$ of all male deaths and $7 \%$ of all female deaths. The average loss of life attributable to tobacco in 1990 was about 16 years ${ }^{2}$. In the last years, many studies have been made to understand the addictive nature of smoking. Nicotine is the principal drug in tobacco products and tobacco smoke responsible for the dependence-producing effects of cigarette smoking. Tobacco addiction is best considered a chronic disease. Cigaratte is considered as a toxic due to its various other components but the nicotine is responsible for its addiction ${ }^{3}$.

Lipids serve as an energy source for the body. They are of various form i.e. high-density lipoproteins (HDLs), low density lipoproteins (LDLs), very low density lipoproteins (VLDL), triglycerides and cholesterol. HDL is considered as a good cholesterol. While others have harmful effects such as cardiovascular disease, narrowing of blood vessels, impair blood flow to the heart, brain and other organs etc. if their levels increased from normal ${ }^{4,5}$. Nicotine responsible for increase in bad cholesterol (LDL, VLDL, triglycerides and cholesterol) and decrease HDL levels. Cigarette smoking (1-5 per day) reported to have a significant risk for a heart attack ${ }^{5}$. 
Lipase catalyses the breakdown of triglycerides into free fatty acids and glycerol. Various kinds of lipases are secreased by various body cells viz. liver (hepatic lipases), adipocytes (hormone-sensitive lipases), vascular endothelial surface (lipoprotein lipase) and small intestine (pancreatic lipase). Understanding lipase is crucial for understanding the pathophysiology of fat necrosis and is clinically significant in the understanding of acute and chronic pancreatitis. The role of lipase is also crucial in the mechanism of some medications indicated for loweringcholesterol ${ }^{6}$. The lipase group of enzymes is built on alpha and beta hydrolase folds. They work by employing chymotrypsin-like hydrolysis, which uses a histidine base, a serine nucleophile and aspartic acid.Each type of Lipase serving individual functions. Hepatic lipase in the liver is responsible for degrading the triglycerides that remain in intermediate density lipoprotein (IDL). Hormone-sensitive lipase is found within fat tissue and is responsible for degrading the triglycerides that are stored within adipocytes. Lipoprotein lipase is found on the vascular endothelial surface and is responsible for degrading triglycerides that circulating from chylomicrons and VLDLs. Pancreatic lipase is found within the small intestine and is responsible for degrading dietary triglycerides ${ }^{7}$. Hepatic lipase plays a crucial role in the formation and delivery of LDL. LDL is formed by the modification of intermediate density lipoprotein in the peripheral tissue and liver by hepatic lipase. These LDL particles are taken up, or endocytosed, via receptor-mediated endocytosis by target cell tissue. LDL serves to ultimately transport cholesterol from the liver to peripheral tissue ${ }^{8}$.

Fat necrosis occurs enzymatically and nonenzymatically. In acute pancreatitis, saponification of peripancreatic fat occurs. In the traumatic events, nonenzymatic fat necrosis takes place which leads to the lipase and fatty acids release and triglyceride breakdown. These negatively charge fatty acids, once released in the bloodstream gets bind to the positively charged calcium ions. This process of salt formation between negatively charged fatty acids and positively charged calcium ions is called saponification ${ }^{9}$. The present study aim to evaluate the effects of smoking on the lipid profile and lipase levels among Iraqi smokers as well as to identify the morbidity risk among smokers and non-smokers.

\section{Materials and Method}

This study was conducted on 50 samples of male subjects in the age group ranging from 19 to 23 years. 10 subjects were non-smokers of cigarette consider as control group and 40 were smokers for cigarette and shisha. All the research participants were explained about the procedures and recruited, after obtaining informed consent. We excluded from the study all Subjects with alcoholics, liver diseases, chronic renal failure, hypothyroidism and diabetes mellitus and also with other chronic illness.

About $5 \mathrm{ml}$ blood samples were collected after an overnight fasting and serum was separated from the blood. The serum lipid profile was studied and the lipid levels were calculated by Freidewald's formula. Estimation of total cholesterol, triglycerides (TGs), lowdensity lipoprotein (LDL) and high-density lipoprotein (HDL) were done by standard method.

\section{Statistical Analysis}

The generated data were depicted as mean \pm standard deviation (SD). The means were compared using an independent sample $t$ test. Analysis was two-tailed and a p-value $\leq 0.05$ was considered as statistically significant. 


\section{Results}

In the present,

Figure 1 showed lipid profile and lipase concentration in control and smoker.

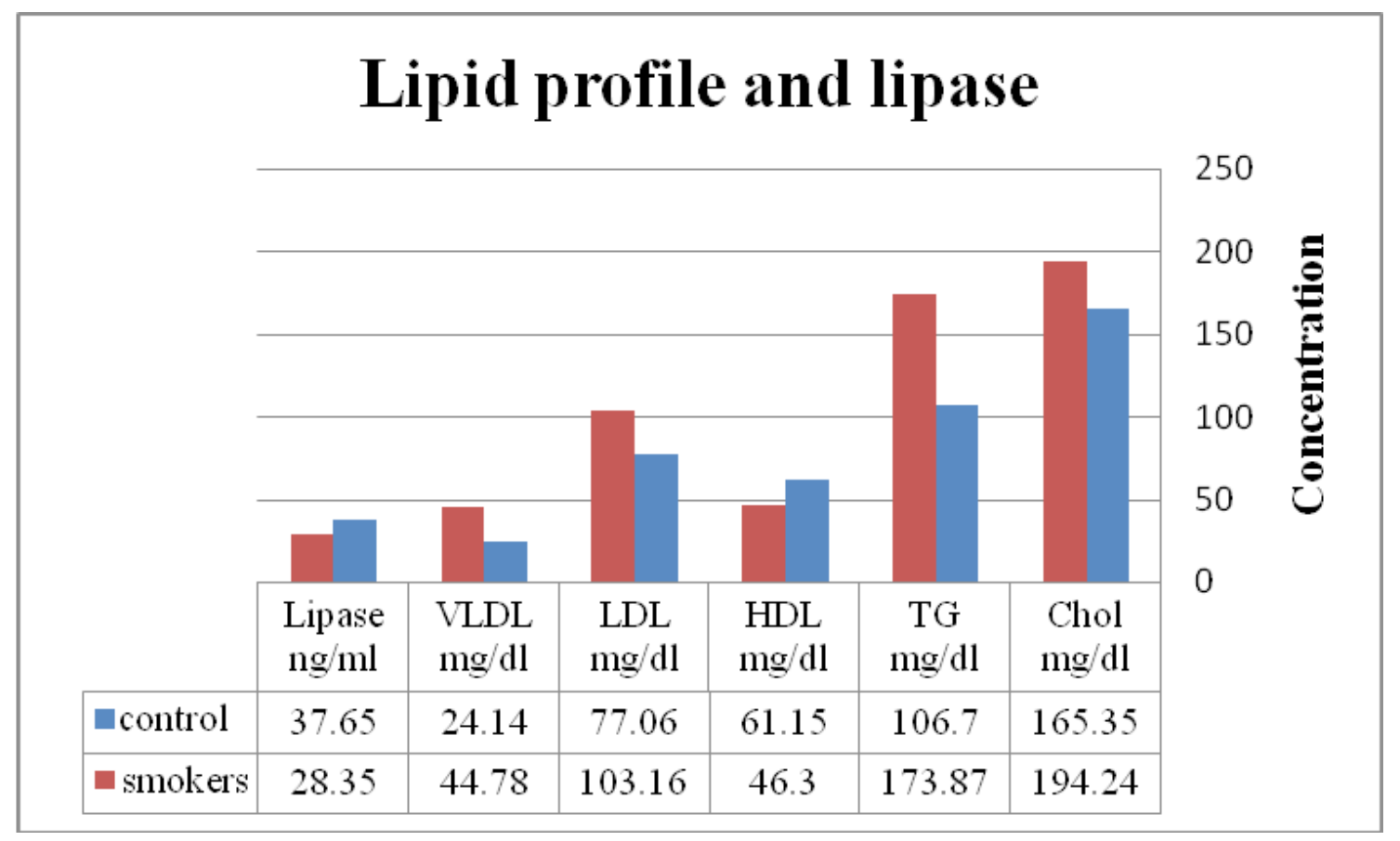

Figure 1. Lipid profile and lipase concentration

The results of the present study indicated as shown in Table 1 to significant differences were observed at $\mathrm{p} \leq 0.05$ in the concentrations of all studied biochemical parameters, which included lipid profile and lipase enzyme concentration when comparing the concentrations of those variables with the control group of non-smokers. Where, the total cholesterol concentration was $165.35 \pm 23.6 \mathrm{mg} / \mathrm{dl}$ in the control group andincreased significantly to $194.24 \pm 37.04 \mathrm{mg} /$ $\mathrm{dl}$ in the group of smokers. The serum triglyceride concentration in the control group was $106.7 \pm 43.4 \mathrm{mg} / \mathrm{dl}$ and increased significantly in the serum of the smokers group to $173.87 \pm 44.96 \mathrm{mg} / \mathrm{dl}$. The results also indicated a significant decrease in the concentration of high density lipoprotein cholesterol (HDL)was the concentration in the control group $64.15 \pm 8.8 \mathrm{mg} / \mathrm{dl}$ and decreased significantly to $46.30 \pm 7.1 \mathrm{mg} / \mathrm{dl}$ in the group of smokers. While, the concentration of low-density lipoprotein LDL increased significantly after its concentration in the control group was $77.06 \pm 20.5 \mathrm{mg} / \mathrm{dl}$ became $103.16 \pm 21.43 \mathrm{mg} / \mathrm{dl}$ in the smokers group. We also observed a significant increase in the level of very low density lipoprotein (VLDL) where the level of serum in the blood of the control group $24.14 \pm 8.8 \mathrm{mg} / \mathrm{dl}$ and the level of serum in the group of smokers $44.78 \pm 8.9 \mathrm{mg}$ / dl. As for the concentration of lipase enzyme, the results indicated a significant decrease in serum enzyme concentration. The serum enzyme concentration in the control group was $37.65 \pm 9.7 \mathrm{mg} / \mathrm{dl}$ and decreased significantly to $28.35 \pm 78.3 \mathrm{mg} / \mathrm{dl}$ in the serum ofsmokers group. 
Table 1. Lipid profile and lipase concentration

\begin{tabular}{|l|c|c|}
\hline Parameters & Control & Smokers \\
\hline Cholesterol $(\mathrm{mg} / \mathrm{dl})$ & $165.35 \pm 23.6$ & $194.24 \pm 37.04$ \\
\hline Triglycerides $(\mathrm{mg} / \mathrm{dl})$ & $106.7 \pm 43.40$ & $173.87 \pm 44.96$ \\
\hline HDL $(\mathrm{mg} / \mathrm{dl})$ & $64.15 \pm 08.80$ & $46.30 \pm 07.10$ \\
\hline LDL $(\mathrm{mg} / \mathrm{dl})$ & $77.06 \pm 20.50$ & $103.16 \pm 21.43$ \\
\hline VLDL $(\mathrm{mg} / \mathrm{dl})$ & $24.14 \pm 08.80$ & $44.78 \pm 08.90$ \\
\hline Serum lipase $(\mathrm{ng} / \mathrm{ml})$ & $37.65 \pm 09.70$ & $28.35 \pm 78.3$ \\
\hline
\end{tabular}

$\mathrm{p} \leq 0.05$, Standard deviation.

\section{Discussion}

Smoking is one of the most important underlying factors that cause significant common risk of atherosclerosis, blood vessels and clinical and genetic diseases. Smoke contains oxidants, of which 4,000 compounds have been identified, causing high cholesterol and triglycerides ${ }^{10}$. These results were consistent with the results of the current study, which indicated an increase in serum lipid concentration (TC, TG, LDL and VLDL)and decreased in HDL in smokers. This may be attributed to the fact that smoking works to find different mechanisms that lead to a change in the level of fat from the most important Nicotine works to stimulate the sympathetic nerves in the adrenal gland, which leads to an increase in the secretion of hormones catecholamines, namely adrenaline and nor- adrenaline and this leads to an increase in lipase and the concentration of free fatty acids in the plasma this in turn leads to increased secretion of hepatic FFA and triglycerides in the bloodstream ${ }^{11-14}$. Another mechanism is due to the condition of hyperinsulinaemia in smokers, this leads to increased cholesterol in the blood as a result of low activity of the enzyme lipase Lipoprotein ${ }^{15}$. Cholesterol levels are important indicators of heart health ${ }^{16}$. For high-density lipoprotein cholesterol or "beneficial" cholesterol, high levels are better. High-density lipoprotein (HDL) is known as "good" cholesterol, because it helps to get rid of other forms of cholesterol from the bloodstream. Higher levels of HDL cholesterol are associated with a lower risk of heart disease $\mathrm{e}^{5}$. Cholesterol is a waxy substance found in all of your cells and has many useful functions, including helping to build your body's cells ${ }^{17}$. They are transported through your bloodstream and are bound to proteins, these are called lipoproteins. High levels of Low-density lipoprotein LDL can eventually build up inside the walls of blood vessels, leading to narrowing of passages ${ }^{18-19}$. Sometimes a clot can form and hang in the narrow distance, causing a heart attack or stroke $\mathrm{e}^{16,20,21}$. Hence, LDL is referred to as "bad cholesterol". Cigarette smoking is associated with a decrease in the level of HDL-C by changing the critical state of fat transfer enzymes, where the activity decreases the ethyl transferase lecithin and cholesterol (LCAT) and change the protein transport cholesterol ester (CETP) and hepatic lipase activity ${ }^{22-24}$. In this study, the results showed that the total serum level of cholesterol, triglycerides, LDL-C and VLDL-C were significantly higher in the smoker compared to non-smokers. The serum level of HDL-C was significantly lower in smokers compared to non-smokers. Previous studies have reported the same results that smokers have a higher picture of fat than non-smokers ${ }^{25-27}$. Other studies indicated that smoking is associated with an increase in total cholesterol levels, triglycerides, LDL-C, VLDL and a decrease in the level of HDL-C ${ }^{28-29}$. Chronic smoking may be the cause of increased levels fats ${ }^{30}$. Due to low lipoprotein lipase activity these studies are consistent and reinforce the results of the present study. A significant decrease in lipase concentration was observed in the smokers group and may be due to decreased secretion or disturbance of enzyme metabolism ${ }^{6}$. This can be attributed in part to some modifications of the acinar tissue or organs involved in lipase metabolism as a result of interaction with the cell membrane or organelles ${ }^{8,7}$. The rise of smoke components can stimulate the reorganization of the lipid membrane There is evidence to suggest that the membrane disorder is caused by a specific type of interaction of smoke components with lipid protein components.Thus, the cell membrane is the main site of action of smoke components and any small changes in the membrane arrangement can produce significant changes in membrane function ${ }^{31-33}$. 


\section{Conclusion}

Cigarette smoking causes a change in lipid profile which includes increased levels of total cholesterol, triglycerides, LDL-C, VLDL-C with a decrease in HDL-C level. Increased smoking intensity led to a greater increase in the concentration of harmful lipoproteins that contribute to atherosclerosis with a decrease in anti-atherosclerotic lipoprotein (HDL-C). Mild smoking is enough to reduce the anti-atherogenic lipoprotein level to the risk of morbidity, an important indicator for predicting the risk of coronary heart disease among smokers. All the above results support the need for an educational program on the dangers of cigarette smoking. In addition, health policy makers should actively promote awareness of the health risks of smoking, clarify the role and risk of smoking in atherosclerosis and implement an effective smoking cessation strategy that is an important factor in reducing the risk of CVD among smokers.

Ethical Clearance: Ethical clearance taken from Iraqi University.

\section{Funding source: Self}

\section{Conflict of Interest: Nil}

\section{References}

1. Berlin I, Robert A. Monoamine oxidases and tobacco smoking. Int J Neuropsychoph,2001,4:33-42.

2. Peto R, Lopez AD, Boreham J, Thun M, Heath C, Doll R. Mortality from smoking worldwide. $\mathrm{Br}$ Med Bull,1996,55: 12-21.

3. Neal L, Benowtiz MD. Neurobiology of nicotine addiction. Implications for smoking cessation treatment. Am J Med,2008,121(4A):S3-S10.

4. Arjun S.S, Vijay K, Jaishree G. Effect of smoking on serum lipid levels: A hospital-based study.J Med Sci,2015,2(1):13-15.

5. Li X.X, Zhao L.X, Huang H.X, Xu X.Y, Liu J.J, Yong P.J, Zhang Y.H Effect of smoking and alcohol consumption on lipid profile in male adults in northwest RURAL CHINA. Int. J. Public Health,2018,157:7-13.

6. Cerk IK, Wechselberger L, Oberer M. Adipose triglyceride lipase regulation: An overview. Curr. Protein Pept. Sci.;2018,19(2):221-233.

7. Waldmann E, Parhofer KG. Apheresis for severe hypercholesterolaemia and elevated lipoprotein (a).
Pathology.; 2019,51(2):227-232.

8. Lotta LA, Stewart ID, Sharp SJ, Day FR, Burgess S, Luan J, Bowker N, Cai L, Li C, Wittemans LBL, Kerrison ND, Khaw KT, McCarthy MI, O’Rahilly S, Scott RA, Savage DB, Perry JRB, Langenberg C, Wareham NJ. Association of genetically enhanced lipoprotein lipase-mediated lipolysis and lowdensity lipoprotein cholesterol-lowering alleles with risk of coronary disease and type 2 diabetes. JAMA Cardiol.,2018,3(10):957-966.

9. Aloysius TA, Carvajal AK, Slizyte R, Skorve J, Berge RK, Bjørndal B. Chicken Protein Hydrolysates Have Anti-Inflammatory Effects on High-Fat Diet Induced Obesity in Mice. Medicines (MDPI),2018;6(1):1-15.

10. Malgorzata S, Anna J, Beats K, Artur K, Jacek $\mathrm{K}$, Elzbieta G. Influence of cigarette smoking on hormone e and lipid metabolism in women in late reproductive stage. Clin Interv Aging. 2019,13:109115.

11. Linda K.G, Heather M.J, Megan E.P, Michael C.F, Timothy B.B, James H.S. Smoking Intensity and lipoprotein abnormalities in active smoking. J. Clin. Lipidol.,2009,3:372-378.

12. Beenakumari R, Balachandran J. A study of dose dependent effect of cigarette smoking on lipid profile. JEvo Med Dentsci.,2015,4(7):1221-1229.

13. Amit D.S, Shyliaja T.V, Asmab M, Zahoorunissa D. Study of lipid profile among healthy smokers and non-smokers. InterJ Biotechnol Biochem,2017,13(1):87-94.

14. Olaniru O.B, Ochalefu D.O, Obeta M.U, Ibanga I.E, Flyaktu Y.B, Jwanse R.I, Orelajo H.A. Assessment of serum lipid profile among male cigasrette smokers in JOS Metropolis. AJBSR,2019,3(6):531-533.

15. Chandrashekar VK, Hemalatha D.N. A study of serum lipid profile in smokers and non-smokers: Evalation or role of smoking on lipid profile. Int J Res Med Sci,2019,7(4):1016-1021.

16. Habib N, Rashid M, Afzal F, Roy B, Tahmina A. Effect of smoking on serum lipid profile amongst stroke patients: A Descriptive study from Dhaka, Bangladesh. J. Biomed. Sci., 2017,4(2):11-15.

17. Ram B.J, Alan D. Associations between smoking and lipid lipoprotein concentrations among US adults aged $\geq 20$ years. J. Circ. Biomark. 2018,7:110.

18. Abdullah A, Wali MM, Israr AA, Ikram DU, 
Muhammad F. Effect of chronic cigarette smoking on lipid profile.PJMHS,2007,1(1):35-37.

19. Poonam K, Mehar B, Govind J.S. Effect of diet and body mass index on the serum lipid profile in healthy premenopausal, per menopausal, and postmenopausal tribal women of India. International Journal of Medical Science and Public Health. 2018,8 (2):120-125.

20. Naser M.E, Zaid M.J, Alyaadi M.J. Effect of cigarette smoking on lipid profile. Lebdmedical Journal. 2018,4:137-139.

21. Sydne I.D, Mohammad A.J, Rajat S.B, John A.A. Enviromental tobacco smoke and cardiovascular diseas. International Journal of Environmental Research and Public health. 2018,16:1-12.

22. Ali F.H, Abdullah S, Alshreef M., Mohamed A. Study of effect of cigarette smoking on hemoglobin and blood lipid profile in males in Black Alshati. Libya. Research Journal of Medical Sciences, 2018,12(6):90-92.

23. Uday B.N, Jinzy M.G, Naveen P.T.V. Serum lipid profile and electrocardiographic changes in young smokers. International Journal of Public Health Science. 2013,2 (1):33-38.

24. Radha A.R, Anjana S.B. Comparison of lipid profile levels in tobacco chewers with and without Leukoplakia-A hospital based study. Annals of Medical and Health Sciences Research. 2017,7:341345 .

25. Elhashimi EH, Haala MG, Zakya A, Abdalla E.A. Effect of cigarette smoking on lipid profile in male collage of police and low Khartom, Sudan. Journal Asian of Biomedical and Pharmaceutical Sciences.,2013,3(26):28-31.
26. Ritienne A, Philip D, Carine J.N, Karen C, Rosienne F, Stephanie R.W. The Impact of passive and active smoking on inflammation, lipid profile and the risk of myocardial infraction. Journal Cardic Risk Factors and Prevention. 2017,4:1-11.

27. Anuja S, Deepa D, Bhaki S. Comparison of the effect of various tobacco habits on the lipid profile in a population of middle-aged Individual: A cross sectional Analytical study. J Contemp Dent., 2018,8(3):115-119.

28. Haragopal H, Anuna BM. Effects of tobacco chewing on serum lipid profile in south India population. IJSS,2016,4(4):9-11.

29. Ram B, Baboo J. Lipid distribution differentials among smokers, non-smokers and within various types of smokers. Ann. Clin. Lab. Res.2017,5(2):168-181.

30. Shatha Hameed Chuweed. A comparison between the effect of Shisha and cigarette smoking on serum lipid profile of males in Nasiriyah city. Med J Babylon. 2018,15: 39-42.

31. Raghu B, Venkatesan P. Relationship between cigarette smoking and novel risk factors for cardiovascular disease. J. Biomed. Sci. 2012,1(4): 1-4.

32. Mohammed A, Omar TH, Hayder A, Abdul Razzaq and Mohamed A.H.The Impact of cigarette smoking on lipid profile among Iraqi smokers. IJCRIMPH. 2016,8(8): 491- 500.

33. Mahshid A, Mahmoud Y, Mostafa H, Alireza O, Gholam Reza H, Mehdi K-O, Hoonan S, Zahra H and Maryam H. Effect of active and passive exposure to cigarette smoke on lipid profile of children and adolescents: A systematic Review and Metaanalysis. Inter J Pediati.,2018,6(5):7575-7588. 